\title{
PERUBAHAN LUAS LAHAN MANGROVE DAN PENGIKISAN PESISIR JEPARA MENGGUNAKAN ANALISIS KOMPONEN UTAMA SPEKTRAL PENGINDERAAN JAUH
}

\author{
Tiara Agustin *, Yudha Kristanto, Ogy Dwi Aulia \\ Prodi Meteorologi Terapan, Departemen Geofisika dan Meteorologi, FMIPA, Institut Pertanian \\ Bogor \\ *Email: tiara.agustin38@gmail.com
}

\begin{abstract}
ABSTRAK
Konversi mangrove menjadi wilayah terbangun di sepanjang pesisir Kecamatan Kedung, Jepara menyebabkan kerentanan wilayah pesisir tersebut terhadap abrasi Laut Jawa. Abrasi telah mengikis wilayah daratan dan menggeser garis pantai. Perubahan luas lahan mangrove dan pergeseran garis pantai dideteksi dengan mengunakan kombinasi kanal merah, NIR, dan SWIR serta rasio kanal merah/SWIR dan SWIR/NIR dari citra Landsat 5 TM, Landsat 7 ETM+, dan Landsat 8 OLI multitemporal 1995-2017. Analisis komponen utama dari semua kanal dan rasio kanal tersebut yang dikombinasikan dengan teknik klasifikasi terbimbing dipilih untuk mengklasifikasikan tutupan lahan, termasuk membedakan vegetasi mangrove dengan vegetasi non mangrove serta membedakan wilayah daratan dengan wilayah lautan. Hasil analisis menunjukkan bahwa perubahan tutupan lahan mangrove menurun sebesar 668,95 ha atau sebesar 55\% selama 1995-2017. Penurunan ini diikuti dengan meningkatnya luasan badan air atau laut akibat abrasi dan kawasan tambak. Laju penurunan tutupan lahan mangrove sebesar 30,7 ha/tahun, sedangkan laju peningkatan kawasan tambak sebesar 31,98 ha/tahun dan laju perubahan tutupan lahan pemukiman berkurang sebesar 15,6 ha/tahun. Akibat abrasi, garis pantai di sepanjang pesisir Kecamatan Kedung bergeser dengan laju 12,6 meter per tahun ke arah darat.
\end{abstract}

Kata kunci: abrasi, kerusakan lingkungan, penutupan lahan, Landsat, analisis perubahan garis pantai

\begin{abstract}
Conversion of mangroves into development areas along the coast of Kecamatan Kedung, Jepara has caused the vulnerability of coastal areas by abrasion of Java Sea. Abrasion has eroded the land area and shifted the shoreline. The decrease of mangrove area and shoreline shift is detected by using channel combination of red, NIR, and SWIR and red / SWIR / SWIR / NIR channel ratios from Landsat 5 TM, Landsat 7 ETM + and Landsat 8 OLI multitemporal 1995-2017 images. Principal component analysis of all channels and the channel ratios combined with supervised classification techniques is selected to classify land cover, including to distinguish non mangrove vegetation with mangrove vegetation and differentiate the area of land with ocean region. The results of the analysis show that the change of mangrove land cover decreased by $668.95 \mathrm{ha}$ or by 55\% during 1995-2017. This decrease is followed by an increase in water or sea area due to abrasion and increasing of pond area. The mangrove land cover decreased at a rate of $30.7 \mathrm{ha} /$ year, while the pond area increased at a rate of 31.98 ha / year and the settlement was reduced by 15.6 ha / year. Due to abrasion, the shoreline in the Kedung region shifts at a rate of 12.6 meters per year landward.
\end{abstract}

Keywords: abrasion, environmental damage, land cover, Landsat, shoreline change analysis

\section{PENDAHULUAN}

Ekosistem mangrove merupakan salah satu ekosistem yang memegang peran penting dalam melindungi daerah pesisir dan terumbu karang (Alongi 2008; Koshiba dkk. 2008; Weiss 2016).
Salah satu peran dari ekosistem mangrove adalah dapat mengakumulasikan bahan organik berupa karbon dan lainnya dalam jumlah yang besar (Alongi 2008; Sanders 2010). Dibandingkan dengan tipe hutan lainnya, 
meliputi hutan pada bagian bumi utara atau boreal, temperate, atau hutan tropis lainnya, jumlah karbon yang dapat disimpan oleh hutan mangrove tiga kali lebih besar, dan lebih dari $60 \%$ total karbon tersimpan di bawah tanah (Donato dkk., 2011).

Ekosistem mangrove di Indonesia merupakan salah satu yang terluas di dunia. Luasan ini mencakup $30.000 \mathrm{~km} 2$ atau hampir $21 \%$ dari jumlah total luas mangrove di dunia (Spalding, 2010). Luas yang sangat besar ini mendapatkan ancaman yang signifikan akibat perubahan penggunaan dan tutupan lahan. Hal ini dibuktikan dengan penurunan luasan hutan mangrove di Indeonesia sejak tahun 1980 2005 sudah mencakup 30\%, dengan penyebab utamanya adalah konversi lahan menjadi tambak udang, lahan pertanian, pengambilan hutan mangrove dalam keperluan hasil hutan, dan lainnya (FAO, 2007). Studi terbaru memperlihatkan bahwa dalam tiga dekade terakhir $40 \%$ dari total mangrove di Indonesia terkonversi, sebagian besar menjadi lokasi budidaya ikan tambak (Murdiyarso dkk., 2015).

Laju pengurangan luasan mangrove di wilayah Indonesia juga dipengaruhi oleh kurangnya perlindungan hukum dari pemerintah dan kesalahan pada pengimplementasian kebijakan pada kalangan yang lebih rendah, seperti pada rencana pembangunan wilayah pesisir (Ilman dkk., 2008). Selain akibat kegiatan manusia degradasi mangrove juga bisa diakibatkan oleh ketinggian air laut, tingkat salinitas, dan bencana alam seperti badai (Gilman dkk., 2008), gempa bumi dan tsunami. Gempa bumi dapat mengangkat beberapa bagian mangrove yang mengakibatkan mangrove mengering dan mati (Ilman dkk., 2008).

Mangrove yang terdegradasi atau terganggu tidak akan mampu mempertahankan ketinggian permukaan relatifnya terhadap ketinggian air laut sehingga meningkatkan tingkat abrasi dan kerentanan wilayah pesisir. Pengaruh ini mecakup berubahnya proses-proses hidrologi, perpindahan nutrien, dan sedimen, yang dihasilkan dari kegiatan manusia, seperti pembangunan jembatan, jalan, ataupun tanggultanggul yang membatasi hubungan prosesproses hidrologi antara samudra dan sungai, atau dampak yang berasal dari kegiatan pertanian (Ellison, 1998; MacKenzie, dkk. 2015).
Kabupaten Jepara merupakan salah satu Kabupaten di Jawa Tengah yang memiliki ekosistem mangrove. Ekosistem ini terbagi dua, yaitu pada daratan utama pulau Jawa dan Kepulauan Karimun Jawa. Kawasan mangrove Kabupaten Jepara merupakan salah satu kawasan mangrove yang mengalami gangguan akibat aktivitas manusia. Aktivitas ini mencakup konversi menjadi perumahan dan tambak. Wilayah tambak biasanya digunakan pada musim basah dan pada musim kering wilayah ini biasanya digunakan sebagai produksi garam yang juga merupakan salah satu mata pencarian utama masyarakat Jepara (Ilman dkk., 2008).

Desa Bulakbaru dan Desa Tanggultlare merupakan salah satu desa yang terletak pada Kecamatan Kedung Kabupaten Jepara. Tidak hanya oleh aktivitas manusia yang mempengaruhi ekosistem mangrove pada desa ini, tetapi juga dipengaruhi tingginya gelombang laut pesisir (Karyono dkk., 2013). Penelitian yang dilakukan Karyono dkk. (2013) menunjukkan pengurangan luasan mangrove pada periode 2004-2010 seluas 408 ha, yaitu dari 12,615 ha menjadi 12,157. Hilangnya ekosistem mangrove meningkatkan proses abrasi, sehingga menyebabkan hilangnya beberapa kawasan pemukiman pada pesisir wilayah Jepara (Setyawan, 2003). Laju abrasi yang terjadi pada perairan Keling Jepara pada tahun 2003-2013 adalah $20.292 \mathrm{~m} 2 /$ tahun dengan laju akresi 3,615 $\mathrm{m} 2 /$ tahun dengan kondisi gelombang berasal dari timur dan barat laut dengan tinggi $0,619 \mathrm{~m}$ dan periode 3,01 detik (Siregar dkk., 2014), dengan selisih antara abrasi dan akresi yang besar dapat menimbulkan masalah lingkungan yang dapat membahayakan wilayah pesisir seperti hilangnya beberapa bagian daratan.

Proses konversi tutupan lahan ekosistem mangrove pada wilayah pesisir Jepara haruslah melibatkan banyak aspek kehidupan agar tidak saling merugikan. Perlu dilakukan kajian seberapa besar laju perubahan lahan di wilayah ini dan dampaknya terhadap lingkungan disekitarnya, terlebih pada kemampuan ekologis ekosistem mangrove tersendiri dalam mencegah abrasi pesisir. Salah satu langkah yang sudah dilakukan selama dua dekade terakhir ini untuk mengamati laju perubahan lahan mangrove adalah dengan menggunakan penginderaan jauh (Seto dan Fragkias, 2007). 
Tutupan kanopi pada ekosistem mangrove digunakan sebagai indikator keberadaan pohon mangrove yang akan dikaji lebih lanjut dalam menilai faktor-faktor yang mengganggu keberadaannya (Monsef dan Smith, 2017).

Penginderaan jauh dapat didefinisikan sebagai ilmu, teknik, atau seni dalam memperoleh informasi dari suatu objek atau fenomena tanpa kontak langsung dengan objek atau fenomena tersebut (Lillesand dkk., 2004). Penginderaan jauh merupakan alternatif yang bisa diandalkan dalam pemetaan langsung wilayah-wilayah yang tidak terjangkau (Kirui, 2013). Menurut Son dkk. (2015), penginderaan jauh memiliki potensi yang baik dalam pemetaan tutupan lahan mangrove dalam berbagai skala, seperti citra dengan skala menengah, Landsat. Hal ini dikarenakan wilayah studi ekosistem mangrove terbagi-bagi (fragmental) sehingga diperlukan data citra dengan resolusi yang baik dalam pemetaan. Citra dengan resolusi rendah tidak cukup untuk mengumpulkan wilayah peta yang kecil dari ekosistem mangrove.

\section{METODE PENELITIAN}

\subsection{Lokasi Kajian}

Penelitian ini menggunakan Kecamatan Kedung dan sebagian kecil wilayah Kabupaten Demak yang berdekatan dengan Kecamatan Kedung sebagai lokasi kajian. Kecamatan Kedung berada di pesisir utara Kabupaten Jepara, Jawa Tengah dengan 18 desa yang sebagian besarnya berada di kawasan pantai utara Jawa dengan batas berupa Laut Jawa di sebelah barat. Letak geografis kecamatan ini berada di $6^{\circ} 38^{\prime} 04.5^{\prime \prime}$ $6^{\circ} 43^{\prime} 35.3^{\prime \prime} \mathrm{LS}$ dan $110^{\circ} 35^{\prime} 34.2^{\prime \prime}-110^{\circ} 41^{\prime}$ $36.2^{\prime \prime}$ BT dengan luas $43.063 \mathrm{~km} 2$ (berdasarkan luas penggunaan tanah tahun 1983) serta merupakan kecamatan dengan ketinggian paling rendah di Kabupaten Jepara, yakni hanya 0-2 mdpl. Wilayah yang dikaji meliputi wilayah pesisir yang terkikis oleh abrasi dengan sampel yang digunakan adalah Desa Bulakbaru dan Desa Tanggultlare. Lokasi ini dipilih karena telah mengalami pengurangan wilayah daratan secara signifikan selama beberapa tahun akibat abrasi hingga menyebabkan masalah lingkungan dan kependudukan.

\subsection{Alat dan bahan}

Alat yang digunakan dalam penelitian ini adalah seperangkat komputer dengan perangkat lunak Microsoft Office 2016, Google Earth, dan
ArcGIS 10.5 dengan tambahan perangkat DSAS (Digital Shoreline Analysis System). Bahan yang digunakan berupa citra satelit dari USGS yakni Landsat 5 TM (tahun 1995, 1997, 1999, 2007, 2008, dan 2011), Landsat 7 ETM+ (tahun 2003), dan Landsat 8 OLI/TIRS (tahun 2013-2017) jalur 120 baris 65 yang diunduh melalui laman http://earthexplorer.usgs.gov, peta batas administrasi Kecamatan Kedung milik BIG yang diperoleh melalui laman http://tanahair.indonesia.go.id, peta tutupan lahan tahun 2009 dan 2011 dari Kementerian Lingkungan Hidup dan Kehutan (KLHK) yang diunduh melalui laman http://webgis.menlhk.go.id, serta citra satelit Google Maps yang tersedia secara online.

\subsection{Pengolahan Awal}

Analisis data dimulai dengan memfokuskan lokasi kajian yakni memotong citra satelit Landsat menjadi wilayah penelitian berdasarkan peta administrasi Kecamatan Kedung menggunakan perangkat ArcGIS. Klasifikasi tutupan lahan dibutuhkan untuk menaksir tutupan lahan mangrove yang berubah, pergeseran garis pantai, dan besar perubahan pada kedua variabel tersebut.

\subsection{Analisis Perubahan Tutupan Lahan} menggunakan Principal Component Analysis

Kanal merah, inframerah dekat NIR, dan inframerah gelombang dekat atau SWIR (berturut-turut kanal 3, 4, dan 5 pada Landsat 5 TM \& Landsat 7 ETM+, dan kanal 4, 5, dan 6 pada Landsat 8 OLI) yang telah dipotong sesuai wilayah kajian dengan dapat mencirikan tutupan lahan tertentu seperti lautan, mangrove, sedimen dan perumahan. Kanal Red, NIR, dan SWIR dipilih untuk membedakan tutupan lahan vegetasi dan non vegetasi, rasio Red/SWIR dipilih untuk membedakan badan air dengan non badan air, dan rasio SWIR/NIR dipilih untuk membedakan vegetasi mangrove dengan non mangrove. Metode klasifikasi tutupan lahan yang digunakan yakni analisis komponen utama (principal component analysis) pada kombinasi kanal 3 (Red), 4 (NIR), 5 (SWIR), rasio 3/5 (Red/SWIR), dan rasio 5/4 (SWIR/NIR) pada Landsat $5 \&$ Landsat 7 atau kanal 4, 5, 6, 4/6, dan 6/5 pada Landsat 8 OLI 
yang dipadukan dengan klasifikasi terbimbing (supervised classification).

Metode Principal Component Analysis (PCA) digunakan dalam mengkompositkan tiga kombinasi kanal dan dua rasio kanal yang digunakan untuk menghasilkan 5 variabel PC baru, yaitu PC1 hingga PC5. Dari kelima variabel PC tersebut, PC1, PC2, dan PC4 yang menampilkan false colour dipilih untuk mengklasifikasikan tutupan lahan secara terbimbing dengan training area yang didapatkan dari peta tutupan lahan KLHK, Google Earth, dan Google Maps online. Selanjutnya, luas masing-masing tutupan lahan dihitung setiap tahunnya (dari citra yang ada) untuk memperoleh luas perubahan tutupan lahan di pesisir Jepara tersebut selama 20 tahun.

\subsection{Analisis Pergeseran Garis Pantai}

Perbatasan antara lautan dan tutupan lahan daratan terluar (pantai, mangrove, dan tambak) dideleniasi untuk mendapatkan batas garis pantai di setiap tahun dari citra yang tersedia menggunakan basemap yang berupa komposit PC1, PC2, dan PC3 dari citra tersebut. Perubahan garis pantai diperoleh menggunakan perangkat tambahan, Digital Shoreline Analysis System (DSAS) pada ArcMap. Baseline diputuskan dengan jarak 100 meter dari garis pantai yang paling dekat daratan, untuk itu garis pantai setiap tahun harus digabungkan (merge).

\subsection{Analisis Laju Perubahan Lahan menggunakan Regresi Linear Sederhana}

Regresi linear sederhana dua varibel digunakan untuk menduga laju perubahan tutupan lahan mangrove dan pemukiman dan korelasi antara keduanya (Tuholske, 2017) dari tahun 19952017. Regresi linear juga diaplikasikan kepada laju perubahan tutupan lahan yang lain, yaitu pemukiman, lahan pertanian, tambak, dan lahan terbuka, sehingga dapat diperoleh pengaruh konversi lahan terbesar setiap tahun yang mempengaruhi tutupan lahan ekosistem mangrove. Hubungan atntara dua variabel pada persamaan regresi akan di representasikan oleh koefisien regresi.

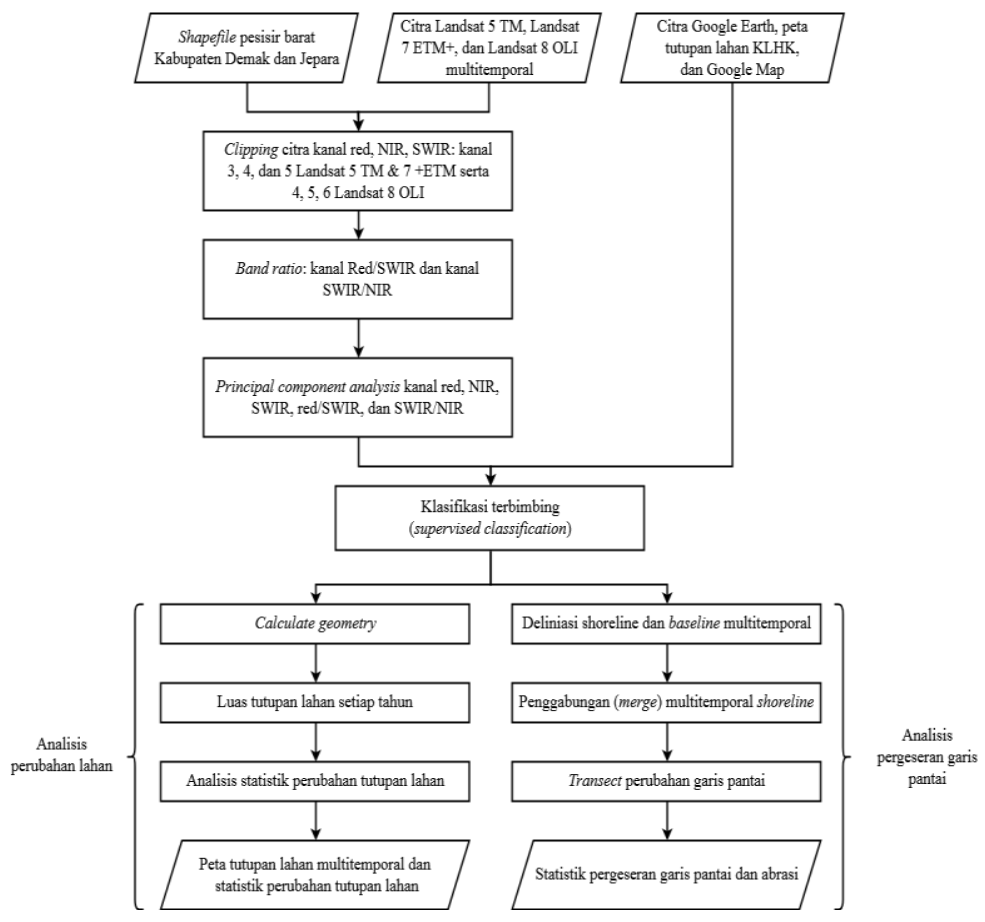

Gambar 1. Metodologi penelitian 


\section{HASIL DAN PEMBAHASAN}

Perubahan tutupan dan penggunaan lahan wilayah Pesisir Demak dan Jepara mengindikasikan penurunan luasan mangrove dan pemukiman yang diikuti dengan kenaikan kawasan tambak dan badan air yang cukup signifikan (Gambar 1). Total area dari lahan terbuka dan vegetasi non mangrove terlihat berfluktuasi dari tahun 1995-2017 (Tabel 1).
Lahan terbuka secara keseluruhan mengalami penurunan dari tahun 1995-2017 sebesar 35\% (Tabel 2), sedangkan pada vegetasi non mangrove secara keseluruhan mengalami peningkatan sebesar $7,74 \%$. Kedua tutupan lahan ini tidak memiliki pengaruh yang siginifikan terhadap perubahan tutupan lahan mangrove.

Tabel 1. Keterangan Tabel ditulis dengan Font 10 Times New Roman

\begin{tabular}{|c|c|c|c|c|c|c|c|}
\hline Tahun & Kanal & Air (Ha) & $\begin{array}{c}\text { Tambak } \\
(\mathbf{H a})\end{array}$ & $\begin{array}{c}\text { Veg. Non } \\
\text { Mangrove } \\
\mathbf{( H a )}\end{array}$ & $\begin{array}{c}\text { Lahan } \\
\text { Terbuka } \\
(\mathbf{H a})\end{array}$ & $\begin{array}{c}\text { Pemukian } \\
(\mathbf{H a})\end{array}$ & $\begin{array}{c}\text { Mangrove } \\
\text { (Ha) }\end{array}$ \\
\hline 1995 & $3,4,5(\mathrm{TM})$ & 18550,44 & 2888,01 & 1323,9 & 957,69 & 1271,79 & 1243,53 \\
\hline 1999 & $3,4,5(\mathrm{TM})$ & 18961,02 & 3098,61 & 1298,25 & 1071,9 & 938,16 & 867,42 \\
\hline 2007 & $3,4,5(\mathrm{TM})$ & 18978,57 & 3424,77 & 1243,08 & 1158,12 & 644,13 & 786,69 \\
\hline 2011 & $3,4,5(\mathrm{TM})$ & 19376,1 & 2853 & 1414,8 & 980,01 & 1030,32 & 581,13 \\
\hline 2014 & $4,5,6(\mathrm{OLI})$ & 18746,01 & 3879,72 & 1236,78 & 1152,18 & 750,24 & 470,43 \\
\hline 2017 & $4,5,6(\mathrm{OLI})$ & 19175,4 & 3609,18 & 1426,41 & 622,35 & 847,44 & 554,58 \\
\hline
\end{tabular}

Tabel 2. Total Perubahan luasan tiap klas perubahan lahan tahun 1995-2017

\begin{tabular}{|c|c|c|c|c|c|c|}
\hline & $\begin{array}{c}\text { Badan } \\
\text { Air }\end{array}$ & Mangrove & Tambak & $\begin{array}{c}\text { Veg. Non } \\
\text { Mangrove }\end{array}$ & $\begin{array}{c}\text { Lahan } \\
\text { Terbuka }\end{array}$ & Pemukiman \\
\hline $\begin{array}{c}\text { Total Perubahan } \\
\text { Lahan (Ha) }\end{array}$ & 624,96 & $-688,95$ & 721,17 & 102,51 & $-335,34$ & $-424,35$ \\
\hline $\begin{array}{c}\text { Total Perubahan } \\
(\%)\end{array}$ & 3,4 & $-55,4$ & 25 & 7,7 & -35 & $-33,4$ \\
\hline
\end{tabular}


Penelitian yang sudah dilakukan menunjukkan bahwa perubahan tutupan lahan mangrove menurun sebesar 668,95 ha atau 55\% selama 1995-2017. Penurunan ini diikuti dengan meningkatnya luasan badan air atau laut akibat abrasi dan kawasan tambak, yaitu masing-masing 624,96 ha $(3,36 \%)$ dan $721,7 \mathrm{Ha}(24,97 \%)$. Gambar 2 menunjukkan kawasan tambak terus dikembangkan di wilayah pesisir Demak dan Jepara yang mana hal ini dipicu dengan adanya tekanan ekonomi dan urbanisasi di wilayah pesisir, sehingga banyak masayakat mencari mata pencarian di wilayah pesisir (Ong 2002). Penurunan mangrove yang terbesar terjadi pada periode 1995-1999 yaitu sebesar 30,24\%, sedangkan peningkatan kawasan tambak terbesar terjadi pada 19992007 yaitu sebesar $10,5 \%$.

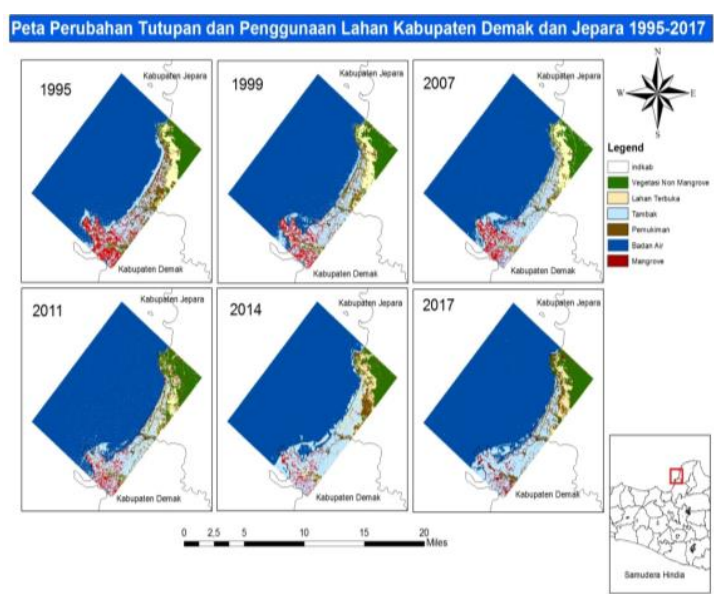

Gambar 2. Peta Perubahan tutupan lahan mangrove tahun 1995-2017
Ekosistem mangrove pada Gambar 2 diperlihatkan dengan warna merah sedangkan tambak warna biru muda, pemukiman warna coklat tua, lahan terbuka warna kuning, badan air warna biru tua, dan vegetasi nonmangrove warna hijau. Hasil interpretasi visual pada setiap piksel perubahan tutupan lahan mangrove pada wilayah barat laut pesisir Demak menunjukkan bahwa perubahan tutupan lahan mangrove dipengaruhi kuat oleh bertambahnya kawasan tambak yang diikuti peningkatan luasan badan air. Gambar 3 menunjukkan hubungan antara mangrove dan tambak pada tahun 1995-2017 menggunakan regresi linear sederhana dengan selang kepercayaan $80 \%$.

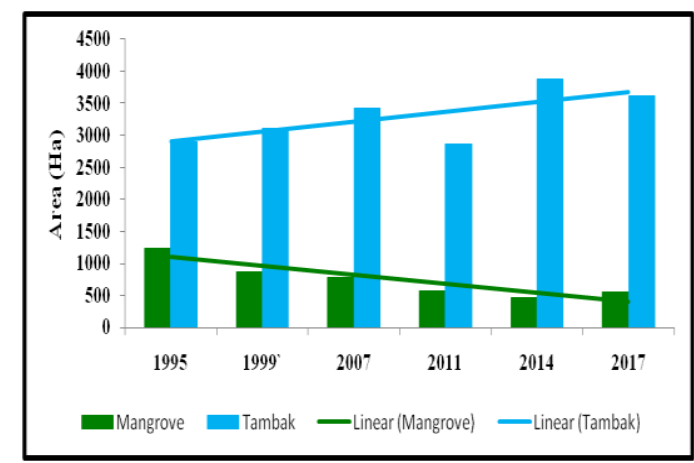

Gambar 3. Hubungan antara mangrove dan tambak menggunakan regresi linear bivariat

Tabel 3. Model regresi linear biavariat sederhana mangrove dan tambak tahun 1995-2017

\begin{tabular}{|c|c|c|c|c|}
\hline & Intersep & Koefisien & R Square & p-value \\
\hline Pendugaan Laju Perubahan 1995-2017 & 62386,99471 & $-30,70814484$ & 0,871173 & $<0,05$ \\
\hline Mangrove & $-60904,59272$ & 31,98379526 & 0,445048 & $<0,2$ \\
\hline Tambak & 32316,35 & $-15,6453$ & 0,370668 & $<0,2$ \\
\hline Pemukiman & 3979,249 & $-0,91528$ & 0,394507 & $<0,001$ \\
\hline
\end{tabular}


Persamaan regresi sederhana digunakan untuk melihat laju perubahan mangrove yang dipengaruhi oleh kawasan tambak serta laju perubahan tutupan lahan mangrove dan tambak setiap tahunnya. Berdasarkan koefisien kemiringan dari model regresi menunjukkan bahwa penurunan 1 ha kawasan mangrove memiliki hubungan dengan bertambahnya 0.9 ha kawasan pemukiman. Model regresi linear juga menunjukkan bahwa kawasan mangrove dengan $p$ value $<0,05$ laju penurunan tutupan lahan mangrove adalah 30,7 ha/tahun sedangkan laju peningkatan kawasan tambak dengan $p$ value $<0,2$ adalah 31,98 ha/tahun dan laju perubahan tutupan lahan pemukiman berkurang 15,6 ha/tahun.

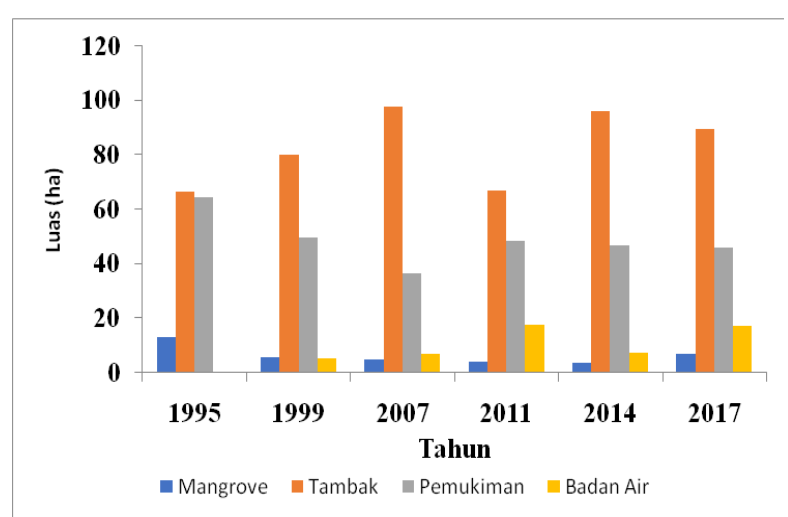

Gambar 4. Luas tutupan lahan Kecamatan Kedung tahun $1995-2017$

Sebagian besar wilayah pesisir Kecamatan Kedung dimanfaatkan untuk usaha tambak masyarakat dan pemukiman. Luas mangrove terus berkurang dalam kurun waktu 22 tahun sebesar 6.156 ha, sedangkan luas tambak meningkat seluas 22,914 ha. Penebangan mangrove mulai menunjukkan dampaknya pada tahun 1999 saat air laut (badan air) telah mengikis daratan pantai seluas 5,265 ha.

Restorasi mangrove dilakukan dalam upaya mengurangi dampak permasalahan lingkungan, terlihat dari kenaikan luasan tutupan lahan mangrove yang meningkat dari 3,627 ha di tahun 2016 menjadi 7,083 ha tahun 2017. Perubahan garis pantai yang diperoleh dari aplikasi DSAS menunjukkan panjang daratan yang terdampak abrasi pada beberapa periode tahun seperti dijelaskan pada Gambar 4. Dalam kurun waktu 20 tahun, perubahan garis pantai yang terjadi di wilayah pesisir Kecamatan Kedung mencapai 12,6 m/tahun. tanpa restorasi mangrove di kawasan ini, dapat diperkirakan daratan yang akan tergerus abrasi akan semakin bertambah.

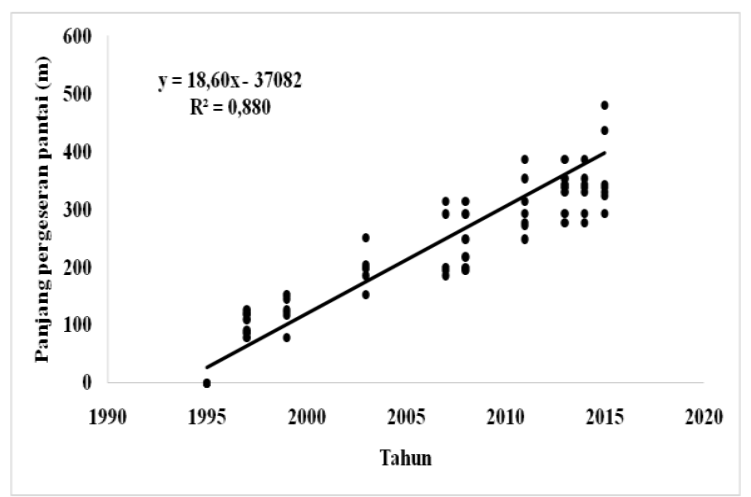

Gambar 5. Perubahan garis pantai Kecamatan Kedung dari tujuh titik pengukuran menggunakan DSAS

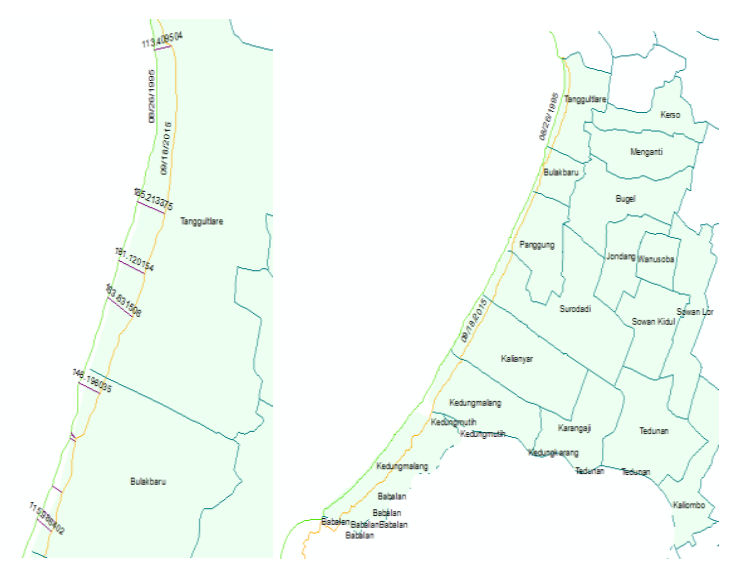

Gambar 6. Pergeseran garis pantai di Kecamatan Kedung (kiri) dan Desa Bulakbaru dan Desa Tanggultlare tahun 1995-2015 (kanan)

Masyarakat di wilayah Kedung telah lama menggunakan wilayah pesisir yang mulanya tertutup mangrove menjadi tempat tinggal dan sumber mata pencaharian dari tambak yang dibangun. Lambat laun perubahan tutupan ini membawa permasalahan lingkungan, Air laut terus menggerus daratan sejauh $36,184 \mathrm{~m}$ hingga 462,719 $\mathrm{m}$ dan mendesak pemukiman warga di sekitar pesisir. 
Desa Kedungmalang yang merupakan wilayah muara sungai mengalami pergeseran garis pantai paling besar, dari $248,931 \mathrm{~m}$ hingga 462,719 m. Desa Tanggul dan Desa Tlare terpaksa bergabung menjadi Desa Tanggultlare akibat abrasi yang menghilangkan sebagian luas daratan kedua desa tersebut. Batas pantai telah berubah hingga 185 meter semenjak tahun 1995 hingga 2015 dan menghilangkan setidaknya $252.500 \mathrm{~m}^{2}$ daratan Desa Tanggultlare. Desa Bulakbaru memiliki luas desa lebih kecil, sehingga kehilangan wilayah daratan sebesar $88.663 \mathrm{~m}^{2}$ selama periode 1995 - 2015 sangat berdampak bagi penduduk pesisir yang kehilangan pemukiman hingga harus merelokasi tempat tinggal mereka.

\section{KESIMPULAN}

Kawasan pesisir Jepara dan Demak merupakan salah satu kawasan yang mengalami tekanan dalam aspek lingkungan. Hal ini dipicu oleh tingginya deforestasi mangrove yang berguna dalam melindungi kawasan pesisir, akibat tekanan ekonomi dan urbanisasi penduduk. Tekanan ini menyebabkan tingginya aktivitas mata pencaharian seperti pengembangan kawasan tambak pada wilayah ini. Laju perubahan tutupan mangrove sejak tahun 1995 hingga 2017 mencapai 30.7 ha/tahun yang dipengaruhi oleh peningkatan tambak yang diikiuti dengan pergeseran garis pantai dengan laju 12.6/tahun ke arah daratan. Penurunan panjang garus pantai akan menimbulkan banyak masalah lingkungan di wilayah ini, seperti meningkatnya abrasi dan intrusi air laut yang nantinya akan menanggu infrastruktur dan aktivitas penduduk lokal.

Kebijakan dalam pengelolaan kawasan pesisir harus melibatkan berbagai aspek sehingga tidak terjadi permasalahan lingkungan yang nantinya akan merugikan masyarakat pesisir. Harus dilakukan upaya peningkatan luasan hutan mangrove yang dapat dilakukan dengan rehabilitasi dan revitalisasi kawasan mangrove yang sudah mengalami kerusakan. Kegiatan ini juga dapat didukung dengan restorasi hutan mangrove (pembibitan dan persemaian) pada wilayah pesisir yang sudah mengalami penurunan kualitas lingkungannya.

\section{UCAPAN TERIMA KASIH}

Pertama-tama tim penulis mengucapkan puji syukur kehadirat Tuhan Yang Maha Esa atas rahmat dan hidayahnya penulis dapat menyelesaikan paper yang berjudul Perubahan Luas Lahan Mangrove dan Pengikisan Pesisir Jepara Menggunakan Analisis Komponen Utama Spektral Penginderaan Jauh.

Ucapan terimakasih juga penulis tujukan kepada tim kuliah kerja nyata tematik (KKN-T) IPB di Desa Bulakbaru, Jepara yang telah memberikan gambaran umum lokasi yang penulis teliti. Tidak lupa, penulis juga mengucapkan terimakasih kepada semua pihak yang telah berperan dalam penyelesaian tulisan ini.

\section{DAFTAR PUSTAKA}

Donato, J.B., Kauffman, D., Murdiyarso, S., Kurnianto, M., Stidham, M., dan Kannien. 2011. Nature Geoscience.4.293-297.

Sanders, J. M., Smoak, AS., Naidu, L.M., Sanders, S., dan Patchineelam R. 2010. Estuarine Coastal and Shelf Science 90.168-172.

Weiss, J., Boy, I., Iskandar, R., Mikutta, G., dan Guggenberger. 2016. Ecologyc and Evolution 6.5043-5050.

Spalding, M. M., dan Kaninuma, L. C. 2010. World Atlas of Mangroves

Murdiyarso, J. P. Kauffman, M. W. Warren, S. D. Sasmito, D. C. Donato, S. Manuri, H. Krisnawati, S. Taberima, S. K. 2015. Nature Climate Change. 8-11.

Ilman, I. T. C., Wibisono, N. N., dan Suryadiputra. 2008. State of the Art Information on Mangrove Ecosystem in Indonesia

Gilman, J. E., dan Duke, N. C. 2008. Field. Aquatic Botany.89.237-250.

MacKenzie, P. B., Foulk, J. V., Klump, K., Weckerly, J., Purbopuspito, D., Murdiyarso, D. C., dan Donato, N. V. N. 2016. Wetlands Ecol Manage 24 245261.

Tuholske, Z., Tane, D., Lopez-carr, D., dan Roberts, S. 2017. Cassels, Applied Geography 88.84-93. 
Lillesand, R. W., dan Kiefer, J. W. 2004. Remote Sensing and Image Interpretation.

Kirui, J. G., Kairo, J., Bosire, K. M., Viergever, S., Rudra, M., dan Huxham, R. A. 2013. Briers, Ocean and Coastal Management, 83.19-24.

Son, C. F., Chen, N. B., Chang, C. R., Chen, L., dan Chang, B. X. 2015. IEE Journal of Selected Topics in Applied Earth Observations and Remote Sensing. 8. 503-510.

Monsef, S. S. 2017. Computers and Electronics in Agriculture, 135. 183-194.

Seto, M. F. 2007. Global Environmental Change, 17. 486-500.

Setyawan, K., dan Winarno, P.C. 2003. Biodiversitas, 4.130-142.

Sinegar, P. S., dan Setiyono H. 2014. Journal of Marine Research. 2. 129-137. 
